\title{
Effect of Gastrointestinal Nematodes on Reproduction and Lamb Growth in Australian Merino Sheep
}

\author{
Hernández-Russo $\mathrm{Z}^{1,2 *}$, Irabuena $0^{1}$, Sterla $\mathrm{S}^{1}$ and Fernández Abella $\mathrm{D}^{1}$ \\ ${ }^{1}$ Production and Reproduction in Ruminants, Department of Biological Sciences, University of \\ Uruguay, Uruguay \\ ${ }^{2}$ Parasitological and Parasitic Diseases, Faculty of Veterinary Medicine, University of Uruguay, \\ Uruguay
}

*Corresponding author: Hernández-Russo Z, Production and Reproduction in Ruminants, Department of Biological Sciences, University of Uruguay, CENUR LN, Rivera 1350, 50000 Salto Uruguay, Email: zhernanrusso@ gmail.com

\section{Abstract}

Environmental conditions in Uruguay favour the development of gastrointestinal nematodes (GIN) throughout the year, with clinical or subclinical manifestations that cause significant economic losses. The aim of this study was to evaluate the effect of the GIN on fertility, fecundity, reproductive rate and lamb growth in Australian Merino sheep grazing on basalt fields. The study was carried out in a farm located in north of Uruguay. Sixty-eight Merino ewes facing a natural parasite challenge were divided into two groups. Control group was doused with active anthelmintic that have proven efficacy to minimize the effects of parasitic and the parasitized group that did not receive anthelmintic, except rescue dosages. Stool sample of each sheep was collected monthly for egg counts (EPG) of GIN using McMaster technique and nematode genders were identified from infective larvae obtained in cultures by Roberts O' Sullivan technique. Artificial insemination and ewes were mated for new service, and pregnancy condition was diagnosed by ultrasound. Lambing control was made and lambs were weighed at birth and marking. The evolution of EPG values showed significant differences between groups at the end of gestation and lactation. Haemonchus spp. was the main gender of nematodes found, followed by Trichostrongylus spp. Fertility was $95 \%$ versus $90 \%$; fecundity 87 $\%$ versus $63 \%$ and reproductive rate $73 \%$ versus $47 \%$ for the control group and the parasitized one respectively. No significant differences were recorded in birth-weight. However market-weight and lamb daily gain were lower in the parasitized group. The effect of natural infection GIN was evident in lower reproductive performance of Australian Merino sheep.

Keywords: Merino sheep; Nematodes; Fertility; Lamb growth

\section{Introduction}

Sheep and cattle can be parasitized by gastrointestinal nematodes (GIN) that are widely distributed throughout the territory of Uruguay. The effects nematodes causes in the production systems are depend of management and environment and therefore variable magnitude of the effect on the parameters evaluated. GNI has been shown to cause a detriment in meat; wool production, sperm concentration and ovulation rate [1-4]. Parasitized ewes showed decrease in lamb survival, in birth-weight and daily gain [5]. In addition, a lower production of milk [6] and a decrease in protein concentration [7], fat and lactose in the milk were observed in parasitized sheep [8]. 


\section{Open Access Journal of Veterinary Science \& Research}

The main objective of the work was to evaluate the effect of GIN on fertility, reproductive rate and on lamb growth of Australian Merino grazing on basalt natural pasture.

\section{Materials and Methods}

The study was carried out in a farm located in the north of the country $\left(31^{\circ} 50^{\prime}\right.$ latitude S, 56 $53^{\circ}$ longitude $\mathrm{W}$ ) and the animal population involved consisted of a total of 68 Australian Merino breeding sheep that faced a natural parasitic challenge was randomly divided into two groups. The control group $(\mathrm{n}=38)$ was dosed with Monepantel $2.5 \%$ and Moxidectin $1 \%\left(4^{\text {th }}\right.$ January, $14^{\text {th }}$ February, $26^{\text {th }}$ April, $4^{\text {th }}$ May, $25^{\text {th }}$ May), of proven effectiveness in minimizing parasitic load and the parasitic group $(n=30)$ received no anthelmintic, except for rescue doses. In each sheep, a sample of GIN's fecal egg counting (EPG) matter was collected monthly (November to July) through Mc Master's technique with saturated salts solution and with a sensitivity of 50 EPG [9].

The gender of nematodes was identified from infecting larvae obtained in cultures using the Roberts O'Sullivan technique. Considering the morphological characteristics of
Larvae 3, parasitic gender was identified [10].

Artificial insemination using fresh semen was performed on November 20, and subsequent mating with rams (3\%) during 39 days.

Pregnancy was diagnosed and fetuses were counted by ultrasonography 60 days after insemination (Aloka SSD 500; 5 MHZ, transrectal probe).

Lambing control was carried out and the lambs were weighed at birth and at the market.

Reproductive parametric were calculated: Fertility (pregnant ewes / inseminated ewes); fecundity (born lambs / inseminated ewes) and reproductive rate (market lambs / inseminated ewes).

Statistical analysis was performed using the SAS statistical package, GENMOD and GLM (Statistical Analysis System Institute, Windows Version 9.2, 2008). EPG data were log transformed for analysis. A difference was considered significant at a probability level of $5 \%$.

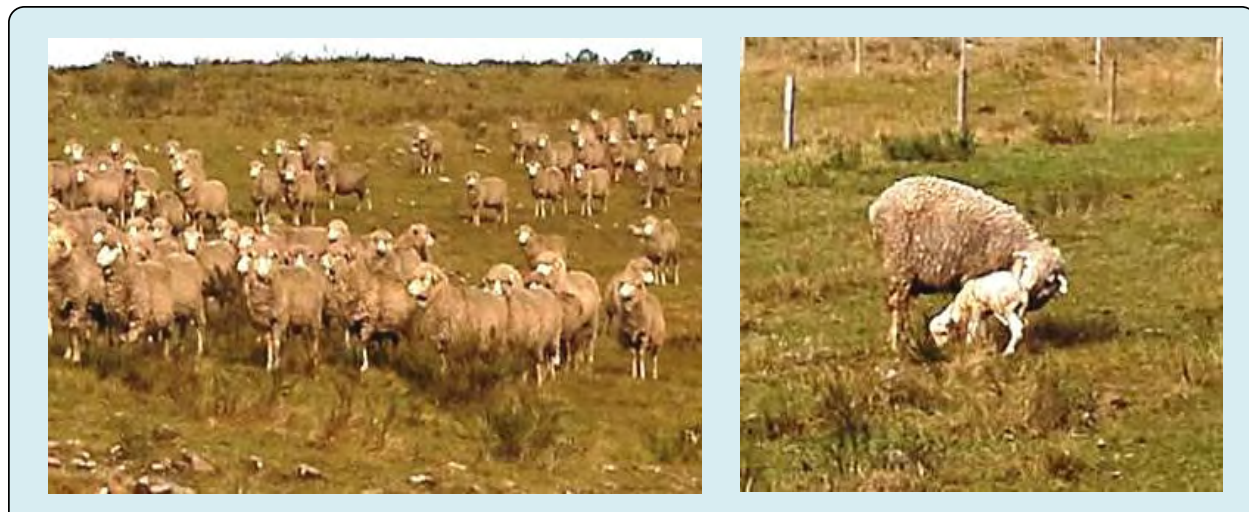

Figure 1: Experimental ewes.

\section{Results and Discussion}

\section{Gastrointestinal Nematode Infection}

EPG values at the start of pregnancy and lactation were 4 versus $61(\mathrm{p}>0.05)$ and 454 versus $4579(\mathrm{p}<0.01)$ for control and parasitized group respectively (Figure 2). The gender of nematodes present were Haemonchus spp., mainly and secondly Trichostrongylus spp.

At the beginning of the trial groups had low parasitic loads (control group 4 EPG and parasitized group $61 \mathrm{EPG}$ ), this can be attributed that previously receiving of periodic dosing and the last one was at the end of October. In the control group from start to June the average parasitic load did not exceed 454 EPG. In turn in the period February March it is observed that the egg counts of nematodes were $<50$ EPG, this may be explained by the high efficacy of $100 \%$ of the anthelmintic drug (Monepantel 2.5\%) used on 14 February in the control of nematodes. At the end of the study in July the counts increased to an average of 1164 EPG.

Parasitized group after the beginning and during the entire period evaluated presented a higher parasitic load with respect to the control group, reaching the maximum average value of $4579 \mathrm{EPG}$ in June. The tendency to increase the values of the counts towards the end of the study in both groups but on different scores coincides with the end of gestation and lactation period and with the phenomenon called "spring rise" $[11,12]$. In "spring rise phenomenon" 


\section{Open Access Journal of Veterinary Science \& Research}

increase in lactation there is a decrease in the immune response of the sheep that together with an activation of the hypobiotic larvae of Haemonchus contortus, lead to a greater elimination of eggs to pastures and consequently an increase in the rate of contamination. There is also an increase in the fertility of adult female nematodes that favors the rise of EPG counts during lactation $[13,14]$. They have been mentioned as causes of decrease immune response to stressors such as under nutrition, climate and gestation, birth and lactation. At the end of gestation and in lactation, energy demand and on the other the susceptibility to parasites are increased [15]. Although the work did not perform the analysis of hypobiotic larvae, it was observed that there was a predominance of the gender Haemonchus.

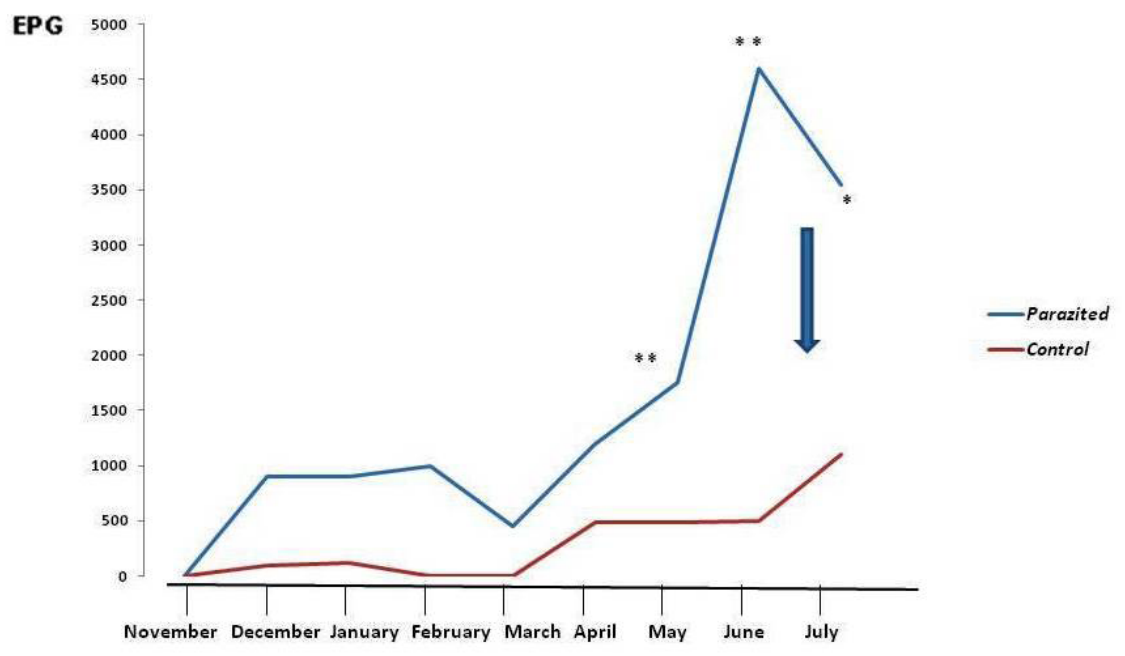

Figure 2: Evolution of parasitic loads of gastrointestinal nematodes in Merino ewes (*: $p<0.05 ; * *$ : $<<0.01)$ : lambing.

\section{Gender of Gastrointestinal Nematodes Observed}

GIN gender recorded through larvae cultures at 4 times during the study period are shown in Figure 2. In this sense, Haemonchus spp. it was present at all opportunities and in higher percentage, between 50 and $95 \%$ of the total infecting larvae evaluated. In contrast, levels of Trichostrongylus spp., Ostertagia spp., and Oesophagostomum spp., fluctuated in different instances between 1 and $18 \%$. This is consistent with several national works that show that haemonchosis is one of the main sheep parasitizes $[1,16]$.

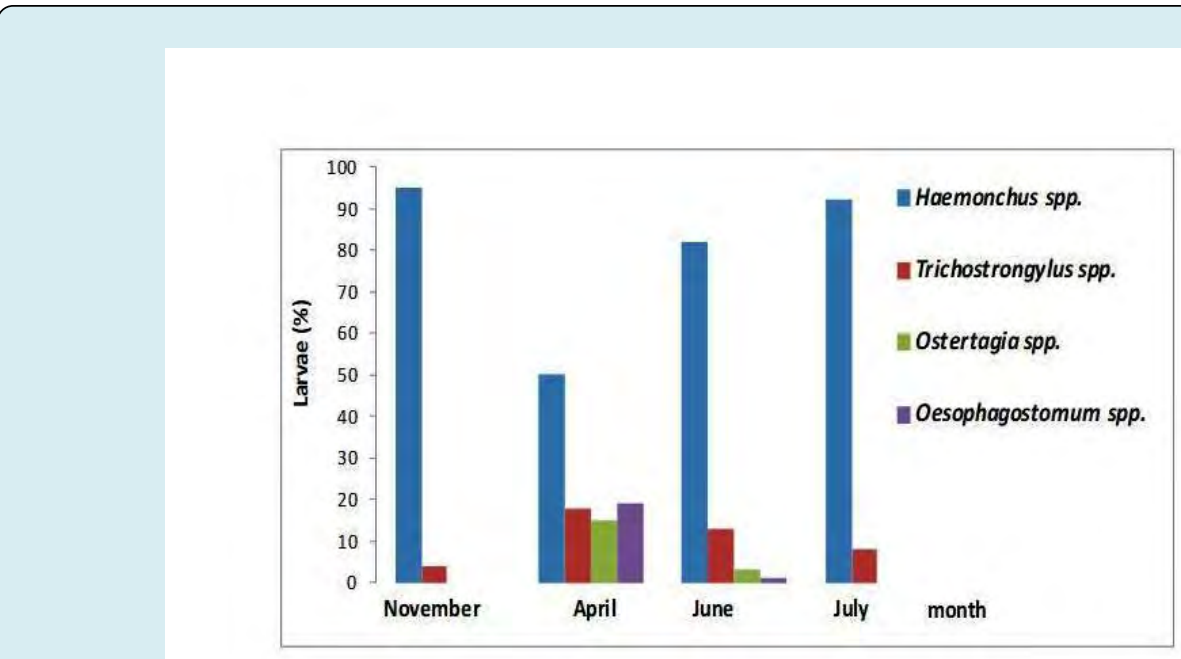

Figure 3: Gender of gastrointestinal nematodes present in larvae cultures during the study period. 


\section{Open Access Journal of Veterinary Science \& Research}

\section{Effects of Gastrointestinal Nematodes on Reproductive Performance of Australian Merino Ewes}

Fertility was $95 \%$ versus $90 \%$, fecundity $87 \%$ versus $63 \%$ and reproductive rate $73 \%$ versus $47 \%$ for the control and parasitized group respectively; differences that were statistically significant (Table 1). On the other hand, there were no significant differences in birth-weight. GIN interferes and competes for nutrients, affecting the digestibility and absorption of nutrients [16], and in this way affecting reproductive performance.

\begin{tabular}{|c|c|c|c|}
\hline Group & Control & Parasitized & P \\
\hline Fertility (\%) & 95.0 & 90.0 & $*$ \\
\hline Fecundity (\%) & 87.0 & 63.0 & $* *$ \\
\hline Reproductive rate (\%) & 73.0 & 47.0 & $* *$ \\
\hline
\end{tabular}

$*^{*}$ p $<0.05 ; * *$ p $<0.01$

Table1: Fertility, fecundity, reproductive rate according to control and parasitized group.

The statistically significant difference in reproductive rates can be explained by the lower fertility recorded in parasitic sheep. It could also be due to a decrease in milk production and the poor condition of sheep parasitic affecting lamb weight-birth [6]. Milk proteins are affected by GIN infection with reductions of $11.9 \%$, as well as decreasing the fat and lactose content by $29.9 \%$ and $19.6 \%$ respectively [8]. In this sense, in sheep of the Lacaune breed with low levels of parasitic infection resulting from the prepartum and postpartum dosing with an anthelmintic administered in the form of slow-release intraruminal bolus, increases in milk production were achieved by $18.5 \%$ [17].

The reproductive rate in the parasitized group (47 \%) was significantly affected, below the national average of around $65 \%$ [16]. In this work, lamb losses were recorded from the partum to the indicated $14 \%$ for the control group and $16 \%$ for the parasitized group.

\section{Evaluation of Effect of Gastrointestinal Nematodes on Lamb Growth}

No significant statistical differences in weight-birth were found. There were differences in weight at marking (40 days older) (Table 2). This was due to increased daily gain in the control group. The average daily gain was $0.169 \mathrm{~kg}$ and 0.136 $\mathrm{kg}$ for control and parasitized lambs respectively.

\begin{tabular}{|c|c|c|c|}
\hline Group & Control & Parasitized & P \\
\hline Birth-weight $(\mathrm{Kg})$ & $3.80 \pm 0.59$ & $3.92 \pm 0.86$ & 0.45 \\
\hline Market weight $(\mathrm{Kg})$ & $10.370 \pm 1.610$ & $8.770 \pm 1.920$ & 0.02 \\
\hline Daily gain $(\mathrm{kg})$ & $0.164 \pm 0.030$ & $0.122 \pm 0.029$ & 0.01 \\
\hline
\end{tabular}

Table 2: Body weight (kg) at the birth and market.

Birth-weight obtained in this study was below the optimal range for the Merino breed ( 4.2 to $4.8 \mathrm{~kg}$ ) established by Fernandez Abella [18], in which the percentage of neonatal death drops to less than $10 \%$. In contrast, in a study conducted by Fernandez Abella, et al. [5] found differences in average birth-weights in dosed sheep versus undosed sheep belonging to the breed Merino. Market weight decrease may be influenced by the lower milk production of parasitized mothers $[17,19,20]$. The growth of lambs especially in the first three to four weeks of life depends fundamentally on the quantity and/or quality of milk provided, taking into account that during the lactation period, the weight gain is proportional to the amount of milk ingested [8]. On the other hand, Mederos, et al. [21] stated that parasitic infections limit live weight gain, soft tissue deposition, muscle growth and milk and wool production.

\section{Conclusion}

In our conditions the effect of natural GIN infection was obvious in a lower reproductive performance of Australian Merino breeding sheep.

\section{References}

1. Hernández-Russo Z, Fernández-Abella D, Kemayd J, Soares De Lima A, Urrutía J, et al. (1999) Efecto de los nematodes gastrointestinales sobre la productividad de ovejas Corriedale y Merino. Peso vivo y crecimiento de lana. Producción Ovina 12: 51-62.

2. Hernández-Russo Z, Villegas N, Fernández-Abella D (2020) Effect of gastrointestinal nematodes in ram sperm production. GSC Advanced Research and Reviews 3(1): 19-25.

3. Fernández Abella D, Castells D, Piaggio L, Deleón N (2006) Estudio de la mortalidad embrionaria y fetal en ovinos. Efecto de distintas cargas parasitarias sobre las pérdidas embrionarias y la fecundidad. Producción 


\section{Open Access Journal of Veterinary Science \& Research}

Ovina 18: 25-31.

4. Fernández-Abella D, Hernández-Russo Z, Villegas N (2006) Effect of gastrointestinal nematodes on ovulation rate of merino Booroola heterozygote ewes (FecB Fec+). Animal Research 55(6): 545-550.

5. Fernández Abella D, Hernández Z, Kemayd J, Soares de Lima A, Urrutia JI, et al. (2000) Efecto de los nematodos gastrointestinales sobre la productividad de ovejas Corriedale y Merino. II. Actividad ovárica, mortalidad y crecimiento de los corderos. Producción Ovina 13: 105115.

6. Familton A, Mcanulti R, Thompson K, Sedcole J (1995) The effect of anthelmintic treatment of ewes during pregnancy. Proceedings of the New Zealand Society of Animal Production 55: 211-213.

7. Rinaldi L, Veneziano V, Cringoli G (2007) Dairy goat production and the importance of gastrointestinal strongly parasitism. Transactions of the Royal Society of Tropical Medicine and Hygiene 101(8): 745-746.

8. Sechi S, Giobbe M, Sanna G, Casu S, Carta A, et al. (2010) Effects of anthelmintic treatment on milk production in Sarda dairy ewes naturally infected by gastrointestinal nematodes. Small Ruminant Research 88(2): 145-150.

9. Thienpont D, Rochette F, Vanparijs O (1986) Diagnosing helminthiasis by coprological examination. 2a. ed. Beerse, Janssen Research Foundation pp: 205.

10. Niec R (1968) Cultivo e identificación de larvas infectantes de nematodes gastrointestinales del bovino y ovino. In: Buenos Aires, (Ed.), Instituto Salesiano de Artes Gráficas, pp: 28.

11. Blitz NM, Gibbs HC (1972) Studies on the arrested development of Haemonchus contortus in sheep. II Termination of arrested development and the spring rise phenomenon. International Journal of Parasitological 2(1): 13-22.

12. Bonino M, Duran del Campo A, Mari J
Enfermedades de los lanares: enfermedades parasitarias. Montevideo, Hemisferio Sur.

13. O'Sullivan BM, Donald AD (1970) A field study of nematode parasite populations in the lactating ewe. Parasitology 61(2): 301-315.

14. Urquhart GM, Armour J, Duncan JL, Dunn AM, Jennings FW (1996) Veterinary Parasitology, $2^{\text {nd }}(E d n$.$) , Chapter 1$ Helminthology, Blackwell Publishing, pp: 12-17.

15. Familton AS (1983) Internal parasites and the growth of lambs. Animal industries workshop, Ministry of Agriculture and Fisheries. Lincoln College, pp: 165-174.

16. Nari A, Cardozo H (1987) Enfermedades causadas por parásitos internos. In: Bonino J, Durán del Campo A, Mari JJ, (Eds.), Enfermedades de los lanares, Hemisferio Sur, Montevideo 1: 1-55.

17. Fthenakis GC, Papadopoukos E, Himonas C (2005) Effects of three anthelmintic regimes on milk yield of ewes and growth of lambs. Journal of Veterinary Medicine A Physiology Pathology Clinical Medicine 52(2): 78-82.

18. Fernández Abella D (2015) Biotecnologías en Bovinos y Ovinos. Mortalidad neonatal de corderos, Facultad de Agronomía, Montevideo, Uruguay 2: 27-46.

19. Thomas RJ, Ali DA (1983) The effect of Haemonchus contortus infection on the pregnant and lactating ewe. International Journal for Parasitology 13(4): 391-398.

20. Cringoli G, Veneziano V, Jackson F, Vercruysse J, Greer AW, et al. (2008) Effects of strategic anthelmintic treatments on the milk production of dairy sheep naturally infected by gastrointestinal strongyles. Veterinary Parasitology 156(3): 340-345.

21. Mederos A (2002) Epidemiología de los nematodos gastrointestinales de los ovinos en Uruguay. Jornada Técnica, Parásitos gastrointestinales en los ovinos: Situación actual y avances de la investigación, INIA SUL, Durazno, Uruguay, pp: 2-5. 